\title{
Secretin Facilitates GABA Transmission in the Cerebellum
}

\author{
Wing-Ho Yung, ${ }^{1}$ Po-Sing Leung, ${ }^{1}$ Samuel S. M. Ng, ${ }^{2}$ Jie Zhang, ${ }^{1}$ Savio C. Y. Chan, ${ }^{1}$ and Billy K. C. Chow ${ }^{2}$ \\ ${ }^{1}$ Department of Physiology, The Chinese University of Hong Kong, Shatin, Hong Kong, and '2Department of Zoology, \\ University of Hong Kong, Pokfulam, Hong Kong
}

\begin{abstract}
Secretin was the first hormone discovered in human history, and yet, its function as a neuropeptide has been overlooked in the past. The recent discovery of the potential use of secretin in treating autistic patients, together with the conflicting reports on its effectiveness, urges an in-depth investigation of this issue. We show here that in the rat cerebellar cortex, mRNAs encoding secretin are localized in the Purkinje cells, whereas those of its receptor are found in both Purkinje cells and GABAergic interneurons. Immunoreactivity for secretin is local-
\end{abstract}

ized in the soma and dendrites of Purkinje cells. In addition, secretin facilitates evoked, spontaneous, and miniature IPSCs recorded from Purkinje cells. We propose that secretin is released from the somatodendritic region of Purkinje cells and serves as a retrograde messenger modulating GABAergic afferent activity.

Key words: secretin; cerebellum; Purkinje cells; GABA; inhibitory postsynaptic currents; autism
Secretin was first discovered as a gastrointestinal hormone by Bayliss and Starling (1902). They showed that an injection of the upper intestinal mucosal extract into an anesthetized dog resulted in the stimulation of pancreatic secretion and hepatic bile flow. To date, the essential role of secretin in regulating secretion of bicarbonate, electrolytes, and volume from pancreatic ductule epithelial cells are firmly established (Daniel, 1991). Other actions of secretin in the digestive system include inhibition of gastric emptying and acid output (Raybould and Holzer, 1993; Jin et al., 1994), stimulation of hepatic bile flow (McGill et al., 1994), and promotion of pancreatic growth (Petersen et al., 1978; Solomon et al., 1978). However, there is still no convincing evidence to indicate the neuroendocrine function of secretin in the CNS, although there is some evidence to suggest that secretin is present in the brain and is neuroactive. For example, secretinlike bioactivity and immunoreactivity were found in mammalian brain extracts (Mutt et al., 1979; O'Donohue et al., 1981). Highaffinity binding sites for secretin have also been detected (Fremeau et al., 1983). Furthermore, secretin increases cAMP concentration in a variety of brain areas (van Calker et al., 1980; Fremeau et al., 1986). However, up to the present, neither has Northern blot analysis detected secretin receptor transcripts in any part of the human brain tested, namely amygdala, caudate nucleus, corpus callosum, hippocampus, substantia nigra, subthalamic nucleus, and thalamus (Chow, 1995), nor has there been any direct electrophysiological evidence to indicate that secretin can modulate the excitability or function of central neurons.

Recently, the question of whether secretin is neuroactive has received a renewed attention. The reported improvement in the behavior of autistic children receiving secretin injections supports this idea (Horvath et al., 1998). However, there are other con-

Received April 13, 2001; revised June 18, 2001; accepted June 26, 2001.

This work has been supported by the Research Grant Council of the Hong Kong Special Administrative Region (China) (Grants HKU416/96M and 7181/99M to B.K.C.C.). We acknowledge Kenny K. W. Ho, David Lam, T. P. Wong, and Ken Yung for their help and Chris H. K. Cheng for reviewing this manuscript.

Correspondence should be addressed to Dr. Billy K. C. Chow, Department of Zoology, Kadoorie Biological Sciences Building, University of Hong Kong, Pokfulam Road, Hong Kong. E-mail: bkcc@hkusua.hku.hk.

Copyright (ㄷ) 2001 Society for Neuroscience $0270-6474 / 01 / 217063-06 \$ 15.00 / 0$ flicting reports on the effectiveness of secretin in treating autism (Sandler et al., 1999; Chez et al., 2000). There is also evidence to suggest a correlation between autism and abnormalities in the cerebellum (Courchesne, 1997; Riva and Giorgi, 2000). These findings thus urge an in-depth investigation on the neuroendocrine roles of secretin, particularly the relevant neuronal pathways and mechanisms involved in exerting its actions. In the present study, we aim to answer these questions by examining the expression of secretin and its receptor in the rat cerebellum as well as the in vitro electrophysiological effects of secretin on central neurons.

\section{MATERIALS AND METHODS}

Northern blot. Poly $(\mathrm{A})^{+}$RNA was prepared from the Sprague Dawley (SDw) rat cerebellum. Five micrograms of the Poly(A) ${ }^{+}$RNA were electrophoresed in a $1 \%$ agarose gel with $0.8 \%$ formaldehyde and transblotted onto a Hybond $\mathrm{N}^{+}$membrane (Amersham Pharmacia Biotech, Arlington Heights, IL). Northern blot hybridization was performed using ${ }^{32} \mathrm{P}$-labeled cDNA encoding rat secretin (nucleotides 1-453) (Kopin et al., 1990) or the N-terminal domain of the secretin receptor (nucleotides 213-639) (Ishihara et al., 1991). The partial cDNAs were produced by RT-PCR using specific primers.

In situ hybridization histochemistry. The rat secretin and secretin receptor partial cDNAs were used to generate digoxigenin-labeled sense and antisense riboprobes using $\mathrm{T}_{3}$ and $\mathrm{T}_{7}$ polymerases, respectively. Cerebella from SDw rats $(n=8$; aged $14-16 \mathrm{~d})$ were fixed with freshly prepared $4 \%$ paraformaldehyde at $4^{\circ} \mathrm{C}$ for $1 \mathrm{hr}$. The fixed cerebella were embedded in paraffin, and sagittal sections $(5 \mu \mathrm{m})$ were cut. The procedures for in situ hybridization were described previously (Leung et al., 1999). Briefly, sections were first digested with proteinase K, rinsed in 0.1 $\mathrm{M}$ triethanolamine, and acetylated in $0.25 \%$ acetic anhydride for $20 \mathrm{~min}$ at room temperature. Prehybridization was performed by incubating sections with $50 \%$ formamide containing $4 \times \mathrm{SSC}$ for $30 \mathrm{~min}$ at $42^{\circ} \mathrm{C}$. Hybridization was performed overnight at $42^{\circ} \mathrm{C}$ in a humidified chamber with antisense or sense riboprobe $(20 \mathrm{ng} / \mu \mathrm{l})$ containing $50 \%$ formamide, $4 \times$ SSC, $0.25 \mathrm{mg} / \mathrm{ml}$ yeast tRNA, $0.25 \mathrm{mg} / \mathrm{ml} \mathrm{salmon} \mathrm{DNA,} 100 \mathrm{mg} / \mathrm{ml}$ dextran sulfate, and $1 \times$ Denhardt's solution. Posthybridized sections were then washed with $2 \times$ SSC containing $50 \%$ formamide at $50^{\circ} \mathrm{C}$. Excess probe was removed by digestion with RNase A $(40 \mu \mathrm{g} / \mathrm{ml})$ for 30 $\min$ at $37^{\circ} \mathrm{C}$. Sections were finally washed sequentially with $2 \times, 1 \times$, and $0.5 \times \mathrm{SSC}$ at $37^{\circ} \mathrm{C}$. Hybridized probes were detected with antidigoxigenin antibody conjugated to alkaline phosphatase (1:500) and visualized by nitroblue-tetrazolium-chloride/5-bromo-4-chloro-indolylphosphate detection kit according to the manufacturer's instructions 
(Roche Diagnostics, Indianapolis, IN). The sections were counterstained with methyl green, dehydrated in a graded ethanol series, and mounted with Permount (Fisher Scientific, Tustin, CA).

Immunohistochemistry. Cerebella from SDw rats were fixed with $4 \%$ paraformaldehyde and embedded in paraffin. Immunocytochemical staining was performed by Vectastain ABC Elite kit (Vector Laboratories, Burlingame, CA) with minor modifications. Briefly, sagittal sections $(5 \mu \mathrm{m})$ of the cerebellum were deparaffinized by xylene, rehydrated in a graded series of ethanol, and treated with $0.3 \% \mathrm{H}_{2} \mathrm{O}_{2}$ in methanol for 30 $\mathrm{min}$. After washing in PBS for $10 \mathrm{~min}$, the sections were incubated with $5 \%$ normal goat serum for $1 \mathrm{hr}$. Excess serum was drained off, and the sections were incubated either with rabbit anti-porcine secretin $(1: 1000)$ (Anawa, Wangen, Switzerland), mouse anti-parvalbumin (1:500), or mouse anti-glial acidic fibrillary protein (GFAP; 1:2000) (Chemicon, Temecula, CA) for $24 \mathrm{hr}$ at $4^{\circ} \mathrm{C}$. After rinsing thoroughly in PBS, the sections were treated with the corresponding anti-rabbit or anti-mouse biotinylated secondary antibody (1:200) for $1 \mathrm{hr}$, followed by incubation with the avidin-biotin-horseradish peroxidase complex reagent for $1 \mathrm{hr}$. The presence of the immunoreactive cells in the cerebellum was detected by $0.05 \% 3,3^{\prime}$-diaminobenzidine tetrahydrochloride in $0.1 \mathrm{M}$ Tris buffer. The sections were counterstained briefly with hematoxylin or methyl green, dehydrated, and mounted. To test the specificity of the immunostaining, the following controls were performed: (1) omission of the primary or secondary antibodies or (2) liquid phase preabsorption of the secretin antiserum with $0.1 \mathrm{~mm}$ porcine secretin (Peninsula Laboratories, Belmont, CA) for $24 \mathrm{hr}$ at $4^{\circ} \mathrm{C}$.

Electrophysiological recordings. Somatic recordings were performed from Purkinje cells in parasagittal cerebellar slices, prepared from 14- to 16-d-old SDw rats, by a conventional patch-clamp amplifier (List Electronics, Darmstadt, Germany). Visualization of the neurons near the top surface of the cerebellar slice was aided by infrared videomicroscopy and differential interference contrast optics. Pipettes were pulled from borosilicate glasses (Sutter Instrument, Novato, CA) and had resistances from 2.2-5 $\mathrm{M} \Omega$ when containing the following internal solution (in $\mathrm{mM}$ ): 140 $\mathrm{KCl}, 2 \mathrm{Na}_{2}$-ATP, $2 \mathrm{MgCl}_{2}, 10$ HEPES, and 1 EGTA. GTP (0.4 mM) was freshly added to the internal solution before experimentation. The artificial CSF (ACSF) contains, in mm: $2 \mathrm{KCl}, 120 \mathrm{NaCl}, 2 \mathrm{MgSO}_{4}, 1.2$ $\mathrm{KH}_{2} \mathrm{PO}_{4}, 26 \mathrm{NaHCO}_{3}, 2.5 \mathrm{CaCl}_{2}$, and 11 glucose. During an experiment, the slices were continuously superfused with the ACSF at a rate of $1.5-2 \mathrm{ml} / \mathrm{min}$. The temperature of the ACSF in the recording chamber was maintained at $34 \pm 1^{\circ} \mathrm{C}$ by a heat-exchanger. Series resistance was checked periodically and typically had values of $\sim 15 \mathrm{M} \Omega$. The series resistance was not compensated, but the recording was abolished when its value changed significantly $(>15 \%)$ during an experiment. The cells were clamped at $-75 \mathrm{mV}$. Spontaneous and TTX-resistant miniature inward synaptic currents were largely abolished by bicuculline methiodide (10 $\mu \mathrm{M})$, indicating that they were $\mathrm{GABA}_{\mathrm{A}}$ receptor-mediated. To evoke inhibitory synaptic currents, 6-cyano-7-nitroquinoxaline-2,3-dione (CNQX; $20 \mu \mathrm{M}$ ) and ( \pm )-2-amino-5-phosphonopentanoic acid (APV; 50 $\mu \mathrm{M})$ were added to the ACSF, and currents were passed from an ACSF-containing pipette in the molecular layer located 50-200 $\mu \mathrm{m}$ from the recording neuron. To evoke EPSCs, bicuculline $(10 \mu \mathrm{M})$ was added in the ACSF. EPSCs originating from the parallel fiber were identified based on their property of paired-pulse facilitation. Data were captured on-line or off-line by the Digidata-pClamp package (Axon Instruments, Foster City, CA) or CED Patch and Voltage Clamp Software Package (Cambridge Electronics Design, Cambridge, UK). Automatic detection and analysis of the spontaneous and miniature IPSCs were performed using home-grown software. Numerical data are expressed as mean \pm SEM. Comparison of the amplitude distribution of IPSCs before and after drug treatment was made by applying the Kolmogorov-Smirnov test; otherwise statistical tests were based on Student's paired or unpaired $t$ tests, as appropriate. Drugs were obtained from the following sources: rat secretin, forskolin (Calbiochem, La Jolla, CA); CNQX, APV, SQ22536, 3-isobutyl-1-methylxanthine (IBMX), bicuculline methiodide (Research Biochemicals, Natick, MA); vasoactive intestinal polypeptide (VIP), pituitary adenylyl cyclase-activating polypeptide (PACAP), Tris-GTP (Sigma, St. Louis, MO); and TTX (Alomone Labs, Jerusalem, Israel).

\section{RESULTS}

By RT-PCR, a conspicuous expression of both secretin and secretin receptors was found in the rat cerebellum (data not shown). To confirm their expression in the cerebellum, we per-
A
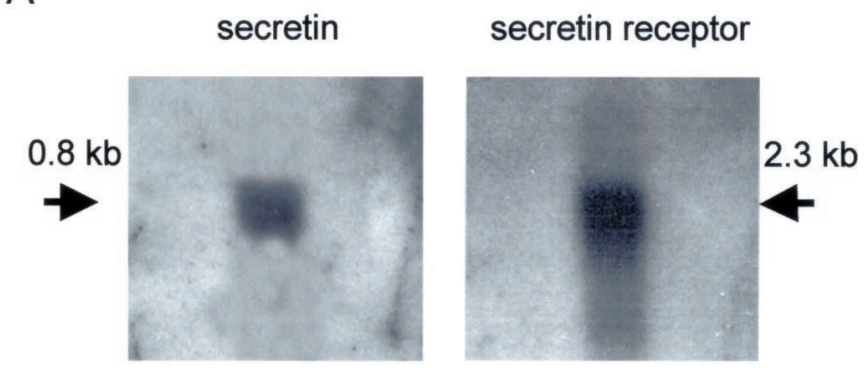

\section{B secretin}
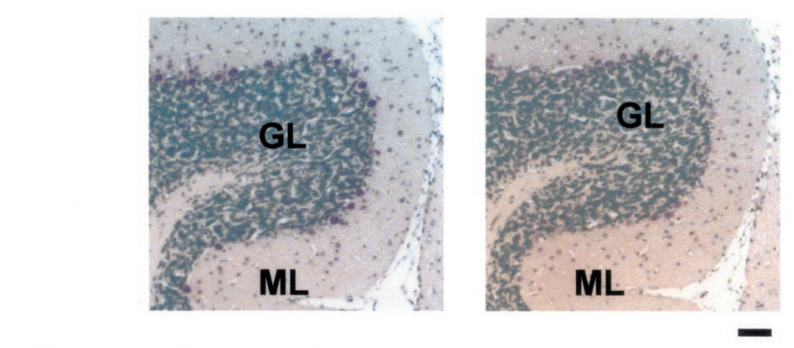

C secretin receptor
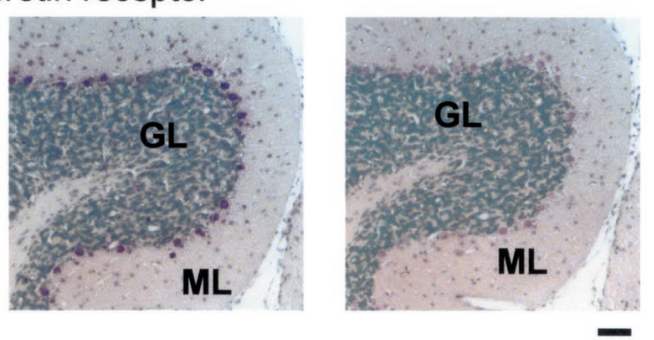

D
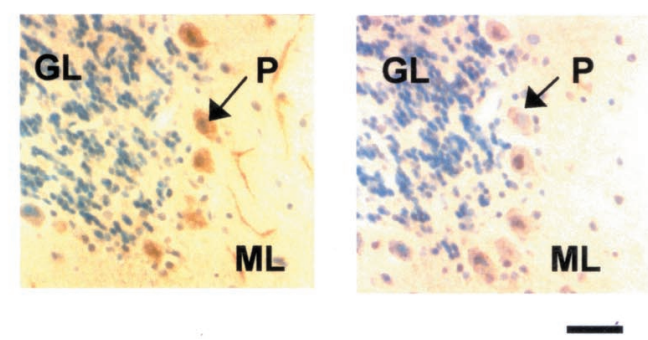

Figure 1. Expression of secretin and secretin receptors in the rat cerebellum. $A$, In Northern blot analysis, positive signals for secretin and its receptor were detected in the cerebellum. B. In in situ hybridization, prominent secretin mRNA signals were found in Purkinje cells when using the antisense (left) probe but not the sense (right) probe. $C$, Purkinje cells also expressed secretin receptor mRNA. Left, Antisense probe; right, sense probe. $D$, Immunoreactivity for secretin was confined to the soma and dendrites of Purkinje cells (left) and was absent in consecutive control sections (right) incubated with antiserum preabsorbed with secretin. Scale bars: $B, C, 100 \mu \mathrm{m} ; D, 40 \mu \mathrm{m}$. $G L$, Granule cell layer; $M L$, molecular layer; $P$, Purkinje cells.

formed Northern blot analysis using partial cDNA probes corresponding to rat secretin (nucleotides 1-453) (Kopin et al., 1990) and the secretin receptor (nucleotides 213-639) (Ishihara et al., 1991). Positive hybridization signals for both the ligand and the receptor were detected in the rat cerebellum (Fig. 1A). To determine the cellular distributions of these transcripts, in situ hybridization studies were performed. It was found that Purkinje cells strongly expressed secretin and secretin receptor mRNAs (Fig. $1 B, C$ ). To confirm the presence of secretin peptide in 
cerebellar Purkinje cells, immunohistochemical staining was performed. In agreement with the data obtained from in situ hybridization, within the cerebellar cortex, secretin immunoreactivity was found only in Purkinje cells. Both the soma and the dendrites of these cells were positively immunostained (Fig. $1 D$ ). In the in situ hybridization, on closer examination, some cells in the molecular layer close to the Purkinje cells were also labeled, albeit more weakly, with the secretin receptor probe. These cells were found mainly in the lower half of the molecular layer, suggesting that they were basket cells. To confirm this, we compared consecutive sections of the in situ hybridization staining with those of immunostaining using antibodies against parvalbumin and GFAP. Parvalbumin is a marker for GABA cells in the cerebellar cortex (Kosaka et al., 1993), whereas GFAP is a marker for glia, including Bergmann glial cells, in the cerebellum (Reichenbach et al., 1995). Figure 2 shows the results of these stainings on consecutive $5 \mu \mathrm{m}$ sections of the cerebellum. Many of the small-sized cells that were stained positively in in situ hybridization (Fig. 2B) were also immunopositive for parvalbumin (Fig. $2 A$ ). On the other hand, GFAP-immunopositive elements had a very different pattern of distribution (Fig. $2 C$ ). These data suggest that basket cells in the cerebellar cortex also express secretin receptors. On the whole, the expression of secretin and its receptor in discrete neuronal types in the brain strongly imply that they serve specific neural functions. The data also suggest that, in the cerebellar cortex, secretin, synthesized and released from the Purkinje cells, is targeted onto basket cells and Purkinje cells themselves.

To elucidate the electrophysiological effects of secretin, we performed whole-cell patch-clamp recordings from Purkinje cells in rat cerebellar slices and examined the action of secretin on the membrane current. Secretin (3-300 nM) did not cause any observable change in the holding current or membrane excitability of Purkinje cells. We next tested the effect of secretin on IPSCs originating from interneurons and EPSCs originating from parallel fibers in the molecular layer (details in Materials and Methods). A brief (3-5 min) exposure to secretin (3-300 nM) resulted in a clear increase in the amplitude and frequency of the spontaneous and evoked IPSCs (Fig. 3A). These actions of secretin had an onset latency of 1-2 min in our system and were longlasting, typically requiring $>30 \mathrm{~min}$ for complete recovery. In seven cells tested, $30 \mathrm{~nm}$ secretin increased the amplitude of the evoked IPSCs to $180 \pm 23 \%(p<0.001)$ and that of the spontaneous IPSCs to $162 \pm 12 \%(p<0.001)$. The action of secretin was specific to IPSCs because the EPSCs evoked by stimulating the parallel fibers were not affected by secretin $(n=$ 4) (Fig. 3B). The potentiation on the amplitude of the evoked IPSCs was also accompanied by a consistent reduction in the paired-pulse ratio (Fig. $3 C$ ). In seven cells, the mean paired-pulse ratio decreased from $0.86 \pm 0.04$ to $0.82 \pm 0.04(p<0.05)$ (Fig. 3C).

The increase in the frequency of the spontaneous IPSCs suggests that secretin may increase the firing of presynaptic neurons. However, this possibility was excluded in basket cells because secretin did not cause any change in whole-cell currents of these cells $(n=3)$ or their firing rate in cell-attached mode $(n=3)$. Nevertheless, the reduction of the paired-pulse ratio of the evoked IPSCs indicates that the effect of secretin has a presynaptic locus of action (Dobrunz and Stevens, 1997). Because a change in the frequency of action potential-independent synaptic currents is a well established indicator of the involvement of a presynaptic mechanism (Van der Kloot, 1991), we examined the effects of secretin on tetrodotoxin (TTX)-resistant, or miniature,
A

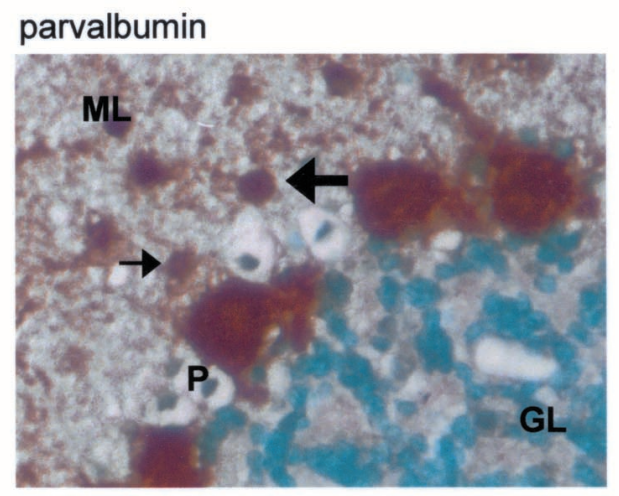

\section{B}

\section{secretin receptor}

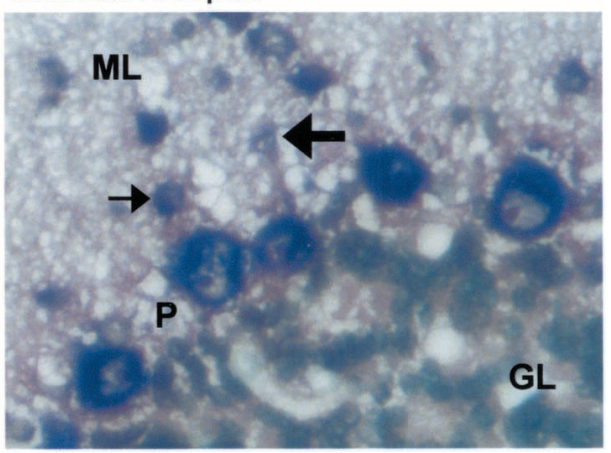

\section{GFAP}

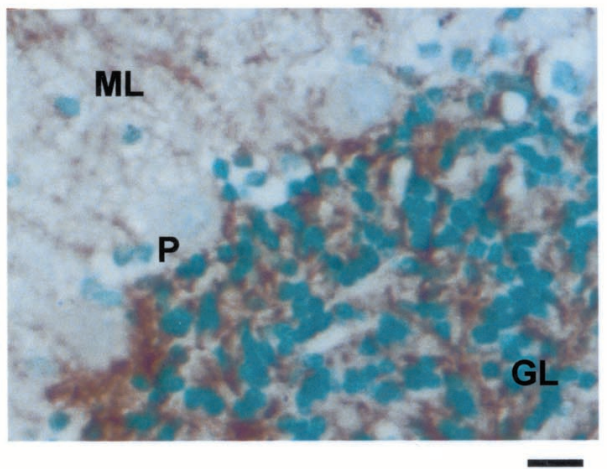

Figure 2. Coexpression of parvalbumin and secretin receptor mRNA in cells in the cerebellar cortex. $A, B$, In these consecutive sections, parvalbumin immunoreactivity and in situ hybridization signals were colocalized in Purkinje cells and some neurons in the molecular layer. The arrows indicate two corresponding neurons in the two sections. $C$, In another consecutive section, GFAP-immunopositive cell bodies were mainly confined in the granule cell layer and did not colocalize with cells labeled in the in situ hybridization. Scale bar, $20 \mu \mathrm{m}$. GL, Granule cell layer; $M L$, molecular layer; $P$, Purkinje cell layer.

IPSCs. Secretin consistently increased the frequency of the miniature IPSCs (Fig. 4A). The effect on the amplitude was, however, more variable. For example, at $30 \mathrm{~nm}$, secretin increased the IPSC amplitude in four of seven cells tested ( $p<0.05$; KolmogorovSmirnov test). Such an increase could be attributed to an increased proportion of larger events. In the rest of the cells, there was no significant change in the amplitude. On average, there was a $10.3 \pm 5.4 \%(n=7)$ increase in the mean amplitude of the miniature IPSCs. The effects of various concentrations of secretin on these parameters are summarized in Figure 4B. A clear 
A

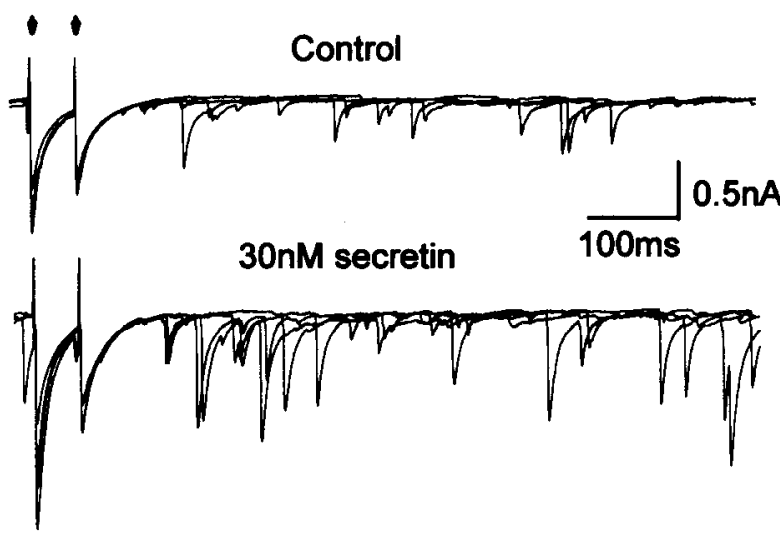

B

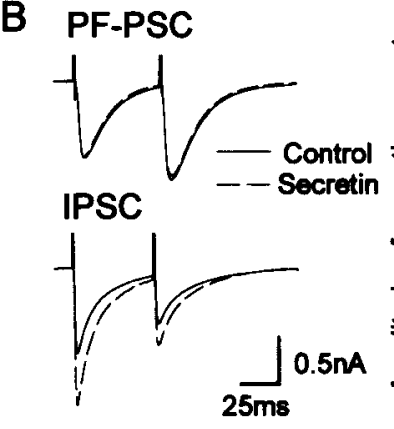

C

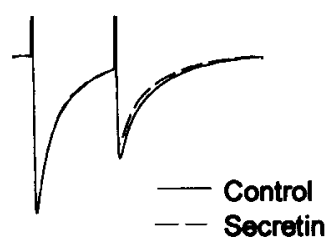

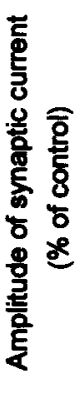

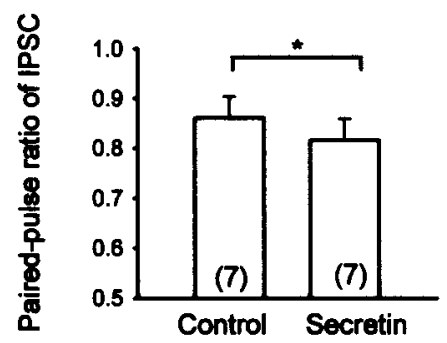

Figure 3. Secretin facilitates GABAergic, but not glutamatergic, synaptic transmission in the rat cerebellum. $A$, Raw traces showing that evoked and spontaneous IPSCs were augmented by bath application of $30 \mathrm{~nm}$ of secretin. Paired stimuli (arrows), separated by a $50 \mathrm{msec}$ interval, were given every $4 \mathrm{sec}$. Four overlaying traces are plotted in each case. $B$, Top traces on the left, which were averaged from 50 evoked IPSCs, revealed that the amplitude and waveform of parallel fiber (PF)-PSC were unaffected by secretin, in sharp contrast to the evoked IPSC shown in the bottom trace. Mean data of the effect of $30 \mathrm{~nm}$ secretin on PF-PSCs and evoked IPSC are shown on the right. $C$, On the left, the normalized IPSCs from the cell shown in $A$ and $B$ revealed a reduction of paired-pulse ratio $\left(\mathrm{IPSC}_{2} / \mathrm{IPSC}_{1}\right)$. Numbers in the parentheses denote the sample size. ${ }^{*} p<$ 0.05 (paired $t$ test); ${ }^{* * *} p<0.001$ ( $t$ test).

dose-dependent relationship was apparent only in the frequency but not the amplitude. These findings indicate that secretin increases the probability of vesicular release from presynaptic terminals. This process may contribute to the observed potentiation on the amplitudes of the evoked and spontaneous IPSCs by secretin. It should be noted that a change in the mean amplitude of the miniature IPSCs is not necessarily inconsistent with a presynaptic mechanism, as has been demonstrated by the presynaptic effect of NMDA in the same synapse (Glitsch and Marty, 1999). For example, secretin may lead to the selective facilitation of a subpopulation of terminals that are associated with larger IPSC amplitudes.

The in situ hybridization data indicated that both Purkinje cells

A
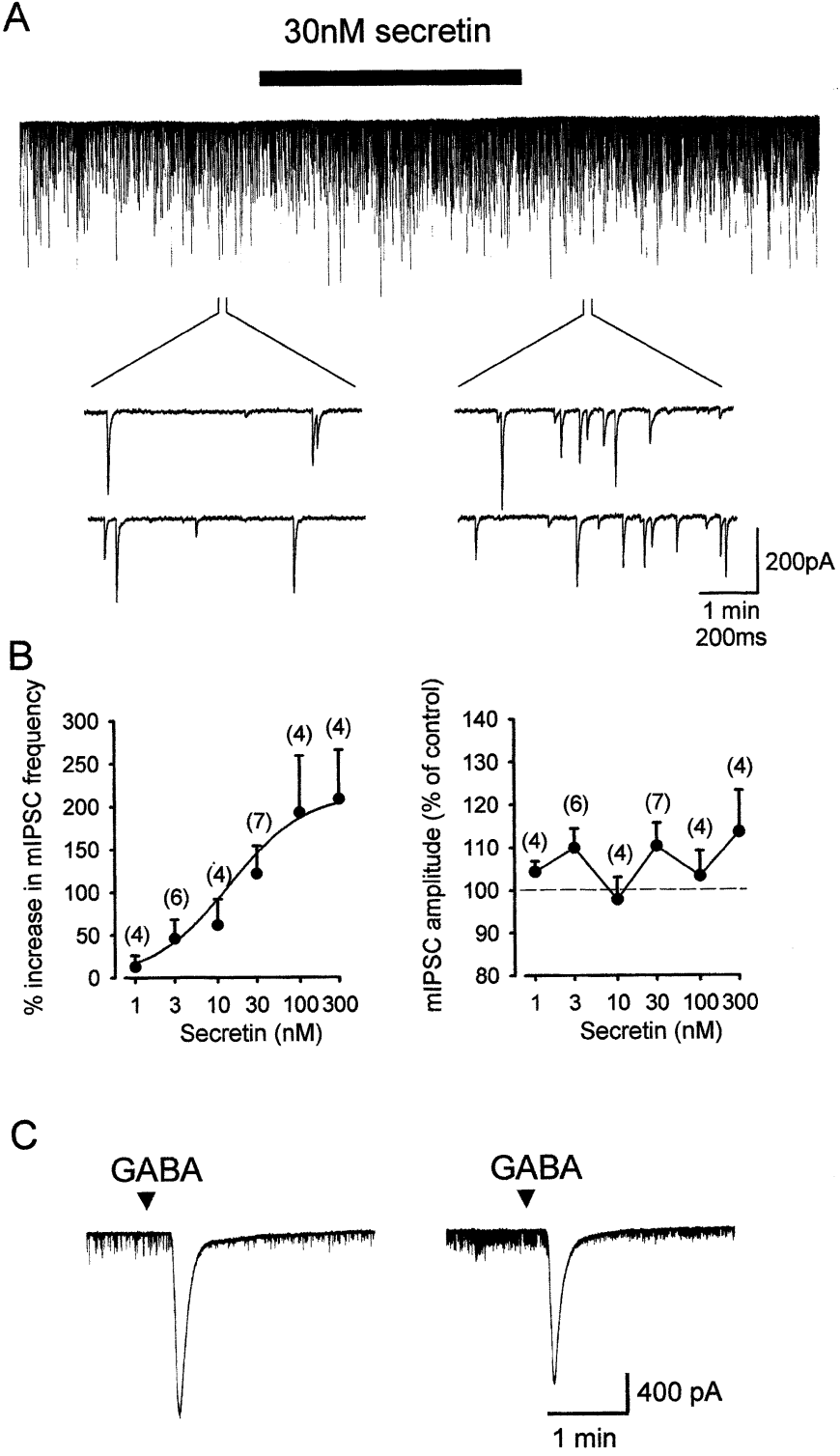

Figure 4. Effect of secretin on miniature IPSCs and postsynaptic $\mathrm{GABA}_{\mathrm{A}}$ receptor sensitivity of Purkinje cells. $A$, A typical experiment showing that secretin increased the frequency of $\mathrm{GABA}_{\mathrm{A}}$-mediated miniature IPSCs. Secretin was added to the superfusion solution for $4 \mathrm{~min}$. Two sets of traces at the time points indicated are shown on a fast time-base. In this cell, recovery from the effect of secretin took $35 \mathrm{~min}$. $B$, Concentration-response curve of the effects of secretin on the frequency (left) and amplitude (right) of the miniature IPSCs. A clear dosedependent effect was found in the frequency only. Numbers in the parentheses denote the number of cells tested. $C$, The postsynaptic sensitivity of $\mathrm{GABA}_{\mathrm{A}}$ receptor of a Purkinje cell in the absence (left) or presence (right) of $30 \mathrm{~nm}$ secretin was compared. Small volumes $(1 \mu \mathrm{l})$ of $0.1 \mathrm{~mm}$ GABA were applied directly to the bath at a fixed distance from the recorded cell.

and basket cells express secretin receptors. To address whether secretin may increase the amplitudes of IPSCs by increasing the sensitivity of postsynaptic $\mathrm{GABA}_{\mathrm{A}}$ receptors on Purkinje cells, we compared the inward current induced by exogenously applied GABA in the absence or presence of secretin. In all cells tested, the peak inward current was not augmented by secretin; instead, an average of $21.8 \pm 9.4 \%(n=6)$ reduction in the amplitude was found (Fig. $4 C$ ). The response partially recovered when secretin 
A

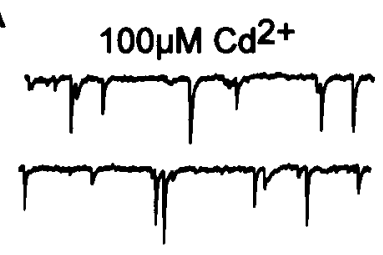

$100 \mu \mathrm{M} \mathrm{Cd}^{2+}+$ secretin mprommprmm

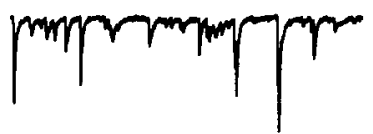

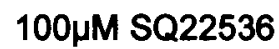

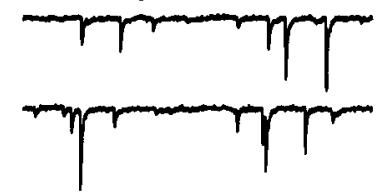

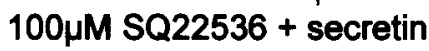

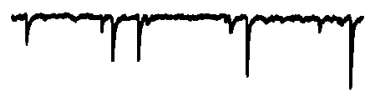

B

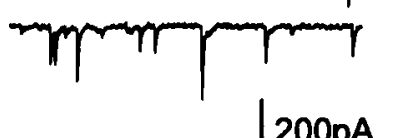

$200 \mathrm{~ms}$

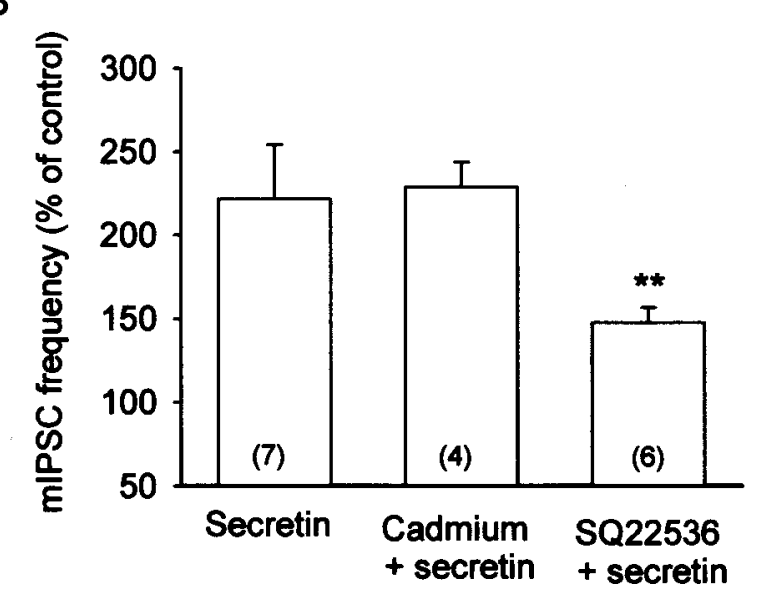

Figure 5. Mechanism of secretin-induced potentiation of miniature IPSCs in Purkinje cells. $A$, The general calcium channel blocker $\mathrm{Cd}^{2+}$ at $100 \mu \mathrm{M}$ did not attenuate the facilitatory effect of secretin on miniature IPSC frequency (top panel). In contrast, SQ22536, a specific inhibitor of adenylyl cyclase, significantly reduced the effect of $30 \mathrm{~nm}$ secretin (bottom panel ). B, Histogram summarizing the effects of $\mathrm{Cd}^{2+}$ and SQ22536 on miniature IPSC frequency. Results are expressed as percentage changes over the control value before addition of the drugs. Numbers in the parentheses denote the number of cells tested in each case; ${ }^{*} p<0.01$.

was removed. At this stage, we are not certain of the nature of this inhibition. Nevertheless, this finding did not support the notion that secretin has a positive modulatory effect on $\mathrm{GABA}_{\mathrm{A}}$ receptors. To test if the facilitatory effects are specific to secretin, VIP and PACAP, two structurally and pharmacologically related neuropeptides, were used, but these peptides did not produce any effect (10 nM; $n=3$ each). In addition, the minimal doses of secretin needed to produce facilitation are at nanomolar concentrations (1-3 nM) and the $\mathrm{EC}_{50}$ value was determined to be at 14 $\mathrm{nM}$, indicating the involvement of secretin receptors only (Rawlings and Hezareh, 1996; Di Paolo et al., 1999). Taken together, these observations support the idea that secretin acts via secretin receptors expressed on basket cell terminals.

The mechanism by which secretin facilitates GABA release was examined in another series of experiments, which were focused on the miniature IPSCs. We first examined the possibility that secretin facilitates vesicular release by augmenting calcium influx (Tiaho and Nerbonne, 1996). As illustrated in Figure $5 A$, the effect of secretin was not sensitive to $100 \mu \mathrm{M} \mathrm{Cd}^{2+}$, a broadspectrum blocker of voltage-dependent $\mathrm{Ca}^{2+}$ channels. These data indicate that the miniature IPSCs are facilitated by a $\mathrm{Ca}^{2+}$ influx-independent mechanism. Because it is well established that secretin increases cAMP concentration in non-neuronal target tissues (McGill et al., 1994; Ulrich et al., 1998) and there is evidence that it has the same action in neuronal tissues (van Calker et al., 1980; Fremeau et al., 1986), the involvement of cAMP as the second messenger was examined. The adenylyl cyclase activator forskolin $(10 \mu \mathrm{M}, n=4)$ and the cAMP phosphodiesterase inhibitor IBMX $(100 \mu \mathrm{M} ; n=3)$ both mimicked the effects of secretin on the miniature IPSC frequency (data not shown). These data were in agreement with previous studies (Llano and Gerschenfeld, 1993; Mitoma and Konishi, 1999). Furthermore, $20 \mathrm{~min}$ of preincubation of $100 \mu \mathrm{M}$ of SQ22536, an inhibitor of the adenylyl cyclase (Lippe and Ardizzone, 1991; Kondo and Marty, 1997), significantly reduced the effect of secretin on the miniature IPSC frequency $(p<0.01 ; n=6)$ (Fig. $5 A)$. SQ22536 itself did not have a clear effect on the mIPSCs. These data, which are summarized in Figure $5 B$, indicate that increased concentration of intracellular cAMP, but not influx of $\mathrm{Ca}^{2+}$, underlies the facilitatory effect of secretin on the mIPSCs. The result, however, does not exclude the possibility that potentiation of the amplitudes of the evoked and spontaneous IPSCs involves augmentation of calcium influx via modulation of voltage-dependent $\mathrm{Ca}^{2+}$ channels or modulation of presynaptic $\mathrm{K}^{+}$conductances.

\section{DISCUSSION}

In this study, we found that secretin and its receptor are expressed in specific neuronal populations of the cerebellar cortex. These data are in line with previous studies showing that secretin immunoreactivity was found in the cerebellum (O'Donohue et al., 1981), which also has the highest secretin binding density in the rat brain (Fremeau et al., 1983). Furthermore, we showed that secretin selectively facilitates GABAergic inputs onto Purkinje cells via a presynaptic and cAMP-dependent mechanism. It is likely that the source of secretin is Purkinje cells, which express secretin mRNA and secretin, and that the peptide acts on its own receptors located on basket cell terminals. These novel actions of secretin, which are distinct from those on the endocrine system (Daniel, 1991; Nussdorfer et al., 2000), strongly support the hypothesis that secretin serves as a neuropeptide in the rat brain. Although secretin was the first hormone discovered in human history, there is still no convincing evidence to indicate that secretin, like other related members in the same peptide family including PACAP, VIP, growth hormone releasing factor (GRF), glucagon, and glucagon like peptide-1 (GLP-1), is also a neuropeptide. Information provided by the present report represents a new piece of the jigsaw puzzle in seeking a complete picture of this family of brain-gut peptides, in terms of their physiology and function.

What is the physiological role of secretin in the cerebellum? One hypothesis that can be formulated is that after depolarization, Purkinje cells release secretin to stabilize themselves by facilitating the inhibitory inputs from the basket cells. The presence of secretin immunoreactivity in the soma and dendrites of Purkinje cells suggests that secretin is released in the somatodendritic region. Analogous somatodendritic release has been postulated for other peptides (Huang and Neher, 1996) and amino acid transmitters (Glitsch et al., 1996; Zilberter et al., 1999). In this context, secretin may serve as a retrograde messenger and produce effects that are opposite to those of glutamate, another 
retrograde messenger postulated in the interneuron-Purkinje cell synapse (Glitsch et al., 1996).

It has been suggested that autism is a genetic disorder (Philippe et al., 1999). Current research links autism to biological or neurological differences in the brain, for instance, abnormalities in the structure of the brain. In fact, abnormalities in the cerebellum, such as the size and number of Purkinje cells, have long been suspected in the etiology of autism (Courchesne, 1997; Riva and Giorgi, 2000). More recently, the involvement of Purkinje cells in this disease has been supported by a rat model of autism in which the cerebellar Purkinje cells of the virally infected brain are selectively destroyed (Pletnikov et al., 1999). Our results therefore provide a link for the speculative relationship between secretin, cerebellum, and autism, as well as an explanation for the potential use of secretin as a drug to treat this disease (Horvath et al., 1998). Furthermore, in view of our observation that secretin and its receptor are also expressed in other brain regions, it is expected that the electrophysiological effects of secretin are not confined to the cerebellum.

\section{REFERENCES}

Bayliss WM, Starling EH (1902) The mechanism of pancreatic secretion. J Physiol (Lond) 28:325-353.

Chez MG, Buchanan CP, Bagan BT, Hammer MS, McCarthy KS, Ovrutskaya I, Nowinski CV, Cohen ZS (2000) Secretin and autism: a two-part clinical investigation. J Autism Dev Disord 30:87-94.

Chow BKC (1995) Molecular cloning and functional characterization of a human secretin receptor. Biochem Biophys Res Commun 212:204-211.

Courchesne E (1997) Brainstem, cerebellar and limbic neuroanatomical abnormalities in autism. Curr Opin Neurobiol 7:269-278.

Daniel EE (1991) Neuropeptide function in the gastrointestinal tract. Boston: CRC.

Di Paolo E, De Neef P, Moguilevsky N, Petry H, Cnudde J, Bollen A, Waelbroeck M, Robberecht P (1999) Properties of a recombinant human secretin receptor: a comparison with the rat and rabbit receptors. Pancreas 19:51-55.

Dobrunz LE, Stevens CF (1997) Heterogeneity of release probability, facilitation, and depletion at central synapses. Neuron 18:995-1008.

Fremeau Jr RT, Jensen RT, Charlton CG, Miller RL, O'Donohue TL, Moody TW (1983) Secretin: specific binding to rat brain membranes. J Neurosci 3:1620-1625.

Fremeau Jr RT, Korman LY, Moody TW (1986) Secretin stimulates cyclic AMP formation in the rat brain. J Neurochem 46:1947-1955.

Glitsch M, Marty A (1999) Presynaptic effects of NMDA in cerebellar Purkinje cells and interneurons. J Neurosci 19:511-519.

Glitsch M, Llano I, Marty A (1996) Glutamate as a candidate retrograde messenger at interneurone-Purkinje cell synapses of rat cerebellum. J Physiol (Lond) 497:531-537.

Horvath K, Stefanatos G, Sokolski KN, Wachtel R, Nabors L, Tildon JT (1998) Improved social and language skills after secretin administration in patients with autistic spectrum disorders. J Assoc Acad Minor Phys 9:9-15.

Huang LYM, Neher E (1996) $\mathrm{Ca}^{2+}$-dependent exocytosis in the somata of dorsal root ganglion neurons. Neuron 17:135-145.

Ishihara T, Nakamura S, Kaziro Y, Takahashi T, Takahashi K, Nagata S (1991) Molecular cloning and expression of a cDNA encoding the secretin receptor. EMBO J 10:1635-1641.

Jin HO, Lee KY, Chang TM, Chey WY, Dubois A (1994) Secretin: a physiological regulator of gastric emptying and acid output in dogs. Am J Physiol 267:G702-G708.

Kondo S, Marty A (1997) Protein kinase A-mediated enhancement of miniature IPSC frequency by noradrenaline in rat cerebellar stellate cells. J Physiol (Lond) 498:165-176.

Kopin AS, Wheeler MB, Leiter AB (1990) Secretin: structure of the precursor and tissue distribution of the mRNA. Proc Natl Acad Sci USA 87:2299-2303.
Kosaka T, Kosaka K, Nakayama T, Hunziker W, Heizmann CW (1993) Axons and axon terminals of cerebellar Purkinje cells and basket cells have higher levels of parvalbumin immunoreactivity than somata and dendrites: quantitative analysis by immunogold labeling. Exp Brain Res 93:483-491.

Leung PS, Wong TP, Sernia C (1999) Angiotensinogen expression by rat epididymis: evidence for an intrinsic, angiotensin-generating system. Mol Cell Endocrinol 155:115-122.

Lippe C, Ardizzone C (1991) Actions of vasopressin and isoprenaline on the ionic transport across the isolated frog skin in the presence and the absence of adenyl cyclase inhibitors MDL12330A and SQ22536. Comp Biochem Physiol C 99:209-211.

Llano I, Gerschenfeld HM (1993) Inhibitory synaptic currents in stellate cells of rat cerebellar slices. J Physiol (Lond) 468:177-200.

McGill JM, Basavappa S, Gettys TW, Fitz JG (1994) Secretin activates $\mathrm{Cl}^{-}$channels in bile duct epithelial cells through a cAMP-dependent mechanism. Am J Physiol 266:G731-G736.

Mitoma H, Konishi S (1999) Monoaminergic long-term facilitation of GABA-mediated inhibitory transmission at cerebellar synapses. Neuroscience 88:871-883.

Mutt V, Carlquist M, Tatemoto K (1979) Secretin-like bioactivity in extracts of porcine brain. Life Sci 25:1703-1708.

Nussdorfer GG, Bahcelioglu M, Neri G, Malendowicz LK (2000) Secretin, glucagon, gastric inhibitory polypeptide, parathyroid hormone, and related peptides in the regulation of the hypothalamus-pituitaryadrenal axis. Peptides 21:309-324.

O'Donohue TL, Charlton CG, Miller RL, Boden G, Jacobowitz DM (1981) Identification, characterization and distribution of secretin immunoreactivity in rat and pig brain. Proc Natl Acad Sci USA 78:5221-5224.

Petersen H, Solomon T, Grossman MI (1978) Effect of chronic pentagastrin, cholecystokinin, and secretin on pancreas of rats. Am J Physiol 234:E286-E293.

Philippe A, Martinez M, Guilloud-Bataille M, Gillberg C, Rastam M, Sponheim E, Coleman M, Zappella M, Aschauer H, van Maldergem L, Penet C, Feingold J, Brice A, Leboyer M (1999) Genome-wide scan for autism susceptibility genes. Hum Mol Genet 8:805-812.

Pletnikov P, Rubin SA, Vasudevan K, Moran TH, Carbone KM (1999) Developmental brain injury associated with abnormal play behavior in neonatally Borna disease virus-infected Lewis rats: a model of autism. Behav Brain Res 100:43-50.

Rawlings SR, Hezareh M (1996) Pituitary adenylate cyclase-activating polypeptide (PACAP) and PACAP/vasoactive intestinal polypeptide receptors: actions on the anterior pituitary gland. Endocr Rev 17:4-29.

Raybould HE, Holzer HH (1993) Duodenal acid-induced inhibition of gastric motility and emptying in rats. Am J Physiol 265:G540-G546.

Reichenbach A, Siegel A, Rickmann M, Wolff JR, Noone D, Robinson SR (1995) Distribution of Bergmann glial somata and processes: implications for function. J Hirnforsch 36:509-517.

Riva D, Giorgi C (2000) The cerebellum contributes to higher functions during development: evidence from a series of children surgically treated for posterior fossa tumours. Brain 123:1051-1061.

Sandler AD, Sutton KA, DeWeese J, Girardi MA, Sheppard V, Bodfish JW (1999) Lack of benefit of a single dose of synthetic human secretin in the treatment of autism and pervasive developmental disorder. N Engl J Med 341:1801-1806.

Solomon T, Petersen H, Elashoff J, Grossman M (1978) Interaction of caerulein and secretin on pancreatic size and composition in rat. Am J Physiol 235:E714-E719.

Tiaho F, Nerbonne JM (1996) VIP and secretin augment cardiac L-type calcium channel currents in isolated adult rat ventricular myocytes. Pflügers Arch 432:821-830.

Ulrich IICD, Holtmann M, Miller LJ (1998) Secretin and vasoactive intestinal peptide receptors: members of a unique family of $\mathrm{G}$ proteincoupled receptors. Gastroenterology 114:382-397.

van Calker D, Muller M, Hamprecht B (1980) Regulation by secretin, vasoactive intestinal peptide, and somatostatin of cyclic AMP accumulation in cultured brain cells. Proc Natl Acad Sci USA 77:6907-6911.

Van der Kloot W (1991) The regulation of quantal size. Prog Neurobiol 36:93-130.

Zilberter Y, Kaiser KMM, Sakmann B (1999) Dendritic GABA release depresses excitatory transmission between layer $2 / 3$ pyramidal and bitufted neurons in rat neocortex. Neuron 24:979-988. 